


\title{
The modern law-making process: structure and main problems
}

\section{DOI: https://doi.org/10.46398/cuestpol.3969.37}

\author{
Mikhail B. Rumyantsev * \\ Vladislav Yu. Turanin ** \\ Sergey Yu. Sumenkov *** \\ Marina G. Smirnova $* * * *$ \\ Esita E. Ganaeva *****
}

\begin{abstract}
Through the dialectical method the objective of the article was to analyze the process of the elaboration of modern laws, considering their structure and main problems. There is a major structure and problems inherent in the modern law-making process described in the article. The structure of law-making comprises four parts: 1 . Cognitive-analytical part; 2 . Theoretical foundations of the legal norms and acts they dictate; 3. Validation of legal act or norm; 4. Monitoring of relevant rules and legal acts. The main legislative task is to draft legal norms that stimulate the active development of all parts of the State and society through a deep perception of all related processes, including those involving standard-setting. It is concluded that the main factor affecting the quality of legislation is the lack of a uniform legislative basis for the issuance of legal acts. There seems to be a real need to develop a uniform legislative act on the law-making process. The Code containing general and specific parts of each law must be developed.
\end{abstract}

Keywords: legislative process; legal norm; structure of the law; problems of legislation; modern laws.

* PhD in Law, FGNC VNIMP names after V.M. Gorbatova, 26, Talalikhina Street, Moscow, 109316, Russia. ORCID ID: https://orcid.org/oooo-0002-9853-5745. Email: mikrumjancev@rambler.ru

** Doctor of Law, Belgorod State University, 85 Pobeda Street, Belgorod, 308015, Russia. ORCID ID: https://orcid.org/oooo-0oo2-3105-9932. Email: turanin@mail.ru

*** Doctor of Law, Penza State University, 40, Krasnaya Street, Penza, 440026, Russia. ORCID ID: https:// orcid.org/oooo-0002-4974-2406. Email: sumenkov@bk.ru

**** Doctor of Law, North-West branch Of the Russian University of Justice, 5, Alexandrovsky Park, St. Petersburg, 197046, Russia. ORCID ID: https://orcid.org/oooo-0002-4427-2505. Email: msm777@ inbox.ru

***** PhD in Law, Chechen state University, 32, A. SHeripova, Groznyj, 364024, Russia. ORCID ID: https://orcid.org/oooo-ooo2-7394-1843. Email: esita4me@mail.ru 
Mikhail B. Rumyantsev, Vladislav Yu. Turanin, Sergey Yu. Sumenkov, Marina G. Smirnova y Esita E. Ganaeva

606

The modern law-making process: structure and main problems

\section{El proceso moderno de elaboración de leyes: estructura y principales problemas}

\section{Resumen}

Mediante el método dialéctico el objetivo del artículo fue analizar el proceso de la elaboración de leyes modernas, considerando su estructura y principales problemáticas. Hay una estructura y problemas principales inherentes al proceso moderno de elaboración de leyes que se describen en el artículo. La estructura de la elaboración de leyes comprende cuatro partes: 1. Parte cognitiva-analítica; 2. Fundamentos teóricos de las normas jurídicas y actos que dictan; 3. Validación de acto o norma jurídica; 4. Seguimiento de las normas y actos legales pertinentes. La principal tarea legislativa es redactar las normas legales que estimulen un desarrollo activo de todas las partes del Estado y de la sociedad a través de una percepción profunda de todos los procesos relacionados, incluidos los que presentan el establecimiento de normas. Se concluye que el principal factor que afecta la calidad de la legislación es la falta de un fundamento legislativo uniforme que determine la emisión de actos jurídicos. Parece surgir la necesidad real de desarrollar un acto legislativo uniforme sobre el proceso de elaboración de leyes. Se debe desarrollar el Código que contiene partes generales y específicas de cada ley.

Palabras clave: proceso legislativo; norma jurídica; estructura de la ley; problemas de la legislación; leyes modernas.

\section{Introduction}

The public relationships are mainly formed in unregulated fashion as affected by social, economic, political and other processes continuously changing in state. The precondition for legal norms issuing is perception of the situations, factors and enactments promoting the development of the public relationships legally regulated for the convenience of social progress. The law-making activity to regulate public relationships is firstly associated with relationships ordering via law norms which requires providing certain forms and patterns - it means the relationships should be formally defined and expressed via language of the terms, categories and institutions which are well-known and familiar to the law sciences (Besson and Martí, 2018; Kozenkova et al., 2021). It should be taken into account that legal normative acts are issued by different law-making bodies differing form each other via rank and competence as well as varied properties. This state of things has a strong influence on available laws and by-laws nature which can often contradict each other (Widiati, 2018; Bobrovnyk et al., 2020). All listed above determines the introduction of the new science with its structure 
and main problems of scientific concerning's. The structure of law-making as new science is closely related to the legal act ranking. Ranking of the statutory acts assumes a subsequence for their location from inferior acts to the superior ones taking into account their power as well as their intersubordination related to other statutory acts (Nemirova and Savelyeva, 2020; Gava et al., 2021).

\section{Methods}

To describe the legal events and facts, the general scientific dialectic method is used. When classifying four parts of law-making as science, different techniques and methods are used. Those are analyses and synthesis, inductive and deductive methods, comparing, formal method. Formal logical approach is used when analyzing the mechanism of creation of the new legal terms dealing with main law-making tasks. Using of techniques and methods from above could add and slightly modify the general dialectic methods to make it to serve the new researching needs and objectives. The new modifications of the method would fill the research objectives they are charged with.

\section{Discussion and Results}

Currently, the legal science mainly considers the law-making process as authorized state bodies' activities aimed to production as well as change and cancels of legal norms (Besson and Martí, 2018; Magradze, 2020). Such approach to understand the law-making addresses pertinently to one of its parties which is legal norm drafting when the legal norm is produced by authorized body and then enforced in acting.

However, the law-making should not be deduced to understand it only as the activity for legal act issuing as far as it solves the broader tasks. In a fair try that the law-making covers even more significant range of activities: 1) Preparation of legal act concept and project; 2) Detection of the need to regulate legally some or other public relationships; 3) Determination of regulative character and power direction (Gava et al., 2021).

The law-making subject also uses other demands to their content: 1) An agreement between public relationships progressively developing, social interests, needs and legal norms; 2) Correctly determined need to regulate legally some or other relationships; 3) Legitimacy of legal acts themselves, their accordance to international, constitutional and other superior norms; 4) An agreement between legal norms and commonly received moral, habit norms, big-hearted, human and fairy ideas, universal values; 
Mikhail B. Rumyantsev, Vladislav Yu. Turanin, Sergey Yu. Sumenkov, Marina G. Smirnova y Esita E. Ganaeva

608

The modern law-making process: structure and main problems

5) Clarity, apprehensibility, lucidity of the legal provisions; 6) Correct determination of legal regulation level; 7) Non-contradictive legal norms, their systematization; 8) Presence of necessary duty norms, the character of the legal sanctions (Bobrovnyk et al., 2020).

In other words, when creating the legal norms, the law-making subjects have to take into account many factors associated not only with standard setting but with solving the tasks of the larger scale: promoting the further development of whole state legal system and public relationships established therein, striking their modernization, preventing of social conflicts and establishing of legal mechanisms for their annihilation, etc (Konasinghe, 2020; Nemirova and Savelyeva, 2020).

The main law-making task is to write the legal norms stimulating an active development of all state and society parts via profound perception of all processes related including those presenting the standard setting. When drafting the legal acts, the law-making subject should resolve the task consisting of three main components: noesis, activity and result, which form relatively complete cycle when their dialectic mutual transition takes place (Konasinghe, 2020). Writing the legal norm outside of this cycle seems not to be possible because its writing must be drawn from the needs that may have been indicated via noesis and procedures of authorized bodies for norm issuing succeeding thereafter.

However, the legal acts developed are not practically sciencebackgrounded, are written topically of the day and do not consider the main trends of social, economic, and political development of state and society. This causes their rapid obsoleting. The legal acts issued do not encourage the public relationships participants to observe them. The law-making subjects formulate the legal provisions mainly via conventional way when behavior rule and sanction for its break-up are provided. In contemporary legal reality, the law-making solution should maximally contain the indorsements for active willful observations of the normative provisions promoted by all parties of relationships via inclusion of all interests in the modification of legal norm. It is understood that legal norms must regulate the public relationships as well as spur their development in the direction and in the interests of all state and society rather than for individual interested group. The law-making subjects give the go-by a stage of perception of the needs for public relationships regulation and so that make the law-making solutions without necessary background, executability, controllability. A durability of such legal acts are also neglected (Umedov, 2021; Gava et al., 2021).

Moreover, the most important factor influencing the whole quality of law-making is the absence of uniform legislative procedures determining an order for drafting and issuing of Russian acts. 
All of these problems and other find out by the scientists are also caused by the fact that legal science describing the law-making process, as uniform law-making activity background had not been yet formed.

So that, the law-making subjects must assume that elaborating the law-making solution is a unified whole process that covers also the noesis or investigation of given public relationships and then the elaborating of legal norms aimed at regulation of the relationships. Without a stage of perception of the nature, content of public relationships, without definition of the grounds causing the objective need to enforce legally the public relationships, it is untenable to include them into the only possible legal form. This is due to the fact that at the first stage the law-making subject investigates the public relationships for the objective need and real possibility to regulate them via legal norms, i.e. percepts their legal content, while at the second stage it creates a project of suitable norm which is capable to provide the qualitative functioning of the relationships, i.e. the form by which the indicated content could be expressed is then determined (Bobrovnyk et al., 2020).

The modern state-of-art of law-making theory as whole systematized legal science constituting the grounds for law-making activity is insufficient (Mcnamara et al., 2019). The law-making sciences and procedures for legal solutions develop without significant interaction. An evident contradiction has raised: the recent needs for scientific comprehension and theoretical background of law-making activity are not firstly taken into considerations by law-making bodies, which continue to issue the legal acts following trials and feedback, and secondly, they are poorly considered in law-making theory that is formed without scientific concept and system in the vagarious way (Nemirova and Savelyeva, 2020).

Numerous papers of Russian scientists concern this problem; a need to create the scientific backgrounds for law-making process is highlighted. The modern legal reform sets out a recent task to modify radically the jurisprudence followed by the setting apart individual norms with legal nature for general state and law theory among which the science dealing with rulemaking and legal workmanship called "nomography" must take rightful place (Magradze, 2020).

"Normographiya" i.e., science dealing with legal workmanships which was presented to the scientific community well qualifies its objective declared because it contains mainly the methodology to product one or others law-making solutions. Nevertheless, law-making theory as individual legal science should not handle such narrow task. As law books note, the law-making theory interest range should include all diversity of lawmaking activities. It begins with the pre-project study of legal regulation scope, scientific background of the need and necessity to enforce legally the relevant public relationships and finishes with standard norm setting carried out during law-making process at all levels. 
Mikhail B. Rumyantsev, Vladislav Yu. Turanin, Sergey Yu. Sumenkov, Marina G. Smirnova y Esita E. Ganaeva

610

The modern law-making process: structure and main problems

Moreover, the law-making theory being individual legal science must have own definitions, idealized theoretical models of solutions for typical social events. Therefore, the law-making theory must produce the scientific criteria of feasibility, quality and effectiveness for such of the solutions, to create own approaches to resolve the law-making tasks, to produce uniform, simple and readable legal terms, categories, institutions etc., that should be friendly to the setting bodies.

Generally, it is necessary to proceed from assumption that law-making as legal science is the law branch determining the public relationships to be regulated via legal norms, establishing the causes for the legal enforcing, proving an objective need to realize the legal provisions in the point of view of legal workmanship and presence of physical, human and other assets to do this well, and in the same way, it is the science studying the methods and procedures to issue the legal acts, ways to change, add and cancel them when considering the social, political and economic processes developing in the state.

As it happens, the law-making theory should be a scientific background of all legal act issuing process rather than standard setting because quality and effectiveness of legal regulation is firstly reached through the foundation of its necessity and subsequently perfectiveness of legal norms issued.

Disregard of appeared needs for theoretical providing of the legal acts intensively issued at all law-making levels is to sidetrack a problem of necessity to transfer the law-making process from empirical field into the hemisphere where the solutions are made based on the scientific knowledge.

Due to this, law-making science should introduce in its subject matter all aspects of the law-making solution elaboration. Therefore, the law-making science must include the following sufficiently separate but then logically bracketed structural elements.

1. Cognitive-analytical part. It is a primary stage allowing the law-making subject to find out and justify the need to regulate certain public relationships in normative manner. The law-making science has to create the procedures to find out such of relationships; to justify the objective needs making the legislator to their normative consolidation; to indicate the criteria by which a possibility to enforce legally the public relationships in view of rule-making procedures, physical assets and form of incorporation for realization of legal norms issued, is assessed; to provide for the determination ways of the consequences which could be appeared due to the legal norm acting; to elaborate the mechanism allowing to resolve the problem about possibility or impossibility to control the legal norm realization.

At presence, it is the most difficult part of the law-making theory because it remains mostly outside of the Russian scientists' eyesight. 
2. Theoretical basics of the legal norms and acts issuing. This is a part concerning directly the issuing of legal norms due to their textual formulating.

The law-making theory has to break new scientific ground for all cycle of legal enforcement of public relationships regulated:

1. Choice of law branch for public relationships to be regulated.

2. Specification of legal norm kind (imperative, dispositive) (Konasinghe, 2020).

3. Scientific background for legal norm content.

4. Proving of use of the modificateur giving the peculiarities to the legal norm realization.

5. Issuing a variation of the legal norm elaborated in accordance to the creative law-making principles etc.

6. Organizational culture is also shown to be an important factor in explaining compliance with the law (Gava et al., 2021).

3. Validation of legal act or norm. This part concerns the process of issuing the legal acts carried out by each of law-making subject.

The law-making theory must produce the most important scientific traits to transfer the scientifically formulated text of the coming legal norms into the range of authorized state provisions mandatory for all persons addressed (Besson and Martí, 2018; Umedov, 2021).

As a rule, it comprises a long-term stage legislatively enforced as certain process regulations. For the present purpose, the law-making task is to create user-friendly and effective mechanism for issuing of qualitative legal norms and acts.

These standards and rules may also stem from other environmental conventions with differing contracting parties. To which kind of standards and rules the reference is made is a question of interpretation and involves the risk of future disputes among the contracting parties and the organization if the reference does not relate to specific instruments (Romanovskaya et al., 2020).

It should be born in mind that law-making process against political parties' competition provides issuing uneasily poor legal acts different by their social, economic, and political content; as a rule, there are the acts voted by the ruling party dominating the parliament. The same phenomenon can be observed in medicine field, where society has chosen to use the concept of the profession as a means of organizing the services of the healer, professionalism has come to serve as the basis of this social 
Mikhail B. Rumyantsev, Vladislav Yu. Turanin, Sergey Yu. Sumenkov, Marina G. Smirnova y Esita E. Ganaeva

contract (Magradze, 2020). The law-making theory task is to find out the better decision to solve this problem.

4. Monitoring of relevant legal norms and acts. This part deals with the control over legal norms issued depending on their objectives and tasks.

This is the prime part of the law-making science because law-making solution monitoring is not systematic now. This leads the collisions between some of legal acts of different levels as well as contradiction of some legal norms against each other. The legal norms are often not geared to perspective and long-term applications, many legal acts are inopportunely changed and added that leads to their slackness, so those acts require to be cancelled (Leino and Curtin, 2017; Mcnamara et al., 2019).

The normative legal background of the law-making legal science is constituted by numerous legislative acts of Russian Federation and its subjects which raises certain difficulties for development of law-making theory terms, categories and institutions, puts back the production of sufficient definitions to percept profoundly the processes associated with production and adoption of the law-making solutions.

As we suppose, clamant necessity to develop the uniform legislative act concerning the law-making process in form of Law-making Code containing the General and Specific Parts has raised. Tolbert P \& Stern R promoted the same idea in their paper (Konasinghe, 2020; Umedov, 2021).

\section{Conclusions}

Thus, as Russian law papers analysis shows, structure of the law-making science must include all processes of issuing legal norms and acts rather than standard setting process only including validation of legal norm. The quality and effectiveness of legal regulation are provided by its groundings and necessity arisen from objective development of the public relationships in the first instance.

The quality of legal norms and acts issued should be surely provided by the law-making subjects. However, if public relationships regulation would not be scientifically grounded i.e. would not resulted from the objective needs then legal act issued, even issued in the best manner from rule-making point of view, would never be effective and so deems to be cancelled. Therefore, the law-making science should comprise all of four structural elements listed above. 


\section{Conflict of Interest}

The authors confirm that the information provided in the article does not contain a conflict of interest.

\section{Acknowledgement}

This article was prepared with the financial support of the Russian Foundation for Basic Research and the Belgorod Region in the framework of the scientific project No. 18-411-310002 "Organizational and Legal Mechanisms for the Systematization of Legal Terminology in the Context of Regional Legislative Activities".

\section{Bibliographic References}

BESSON, Samantha; MARTÍ, José Luis. 2018. "Legitimate actors of international law-making: towards a theory of international democratic representation” In: Jurisprudence. Vol. 9, No. 3, pp. 504-540.

BOBROVNYK, Svitlana V; SHEVCHENKO A. Ie; DIDYCH, Taras O; KHODANOVYCH, Vitalii O; DEI, Maryna O. 2020. "Formal Manifestation of Law Making as an Object of Methodological Strategy of Modern Law Knowled” Vol. 9, No, 05, pp. 959-972. Available online. In: http://ir.nusta.edu.ua/jspui/handle/123456789/6470. Consultation date: $28 / 12 / 2020$.

GAVA, Roy; JAQUET, Julien M; SCIARINI, Pascal. 2021. "Legislating or rubber-stamping? Assessing parliament's influence on law $\square$ making with text reuse" In: European Journal of Political Research. Vol. 6o, No. 1, pp. 175-198.

KONASINGHE, Kokila. 2020. "NGOs as loudspeakers: Potential role of NGOs in bridging the north-south gap in international environmental and sustainable development law making process" In: Sustainability and Law. Vol, 23, pp. 355-375.

KOZENKOVA, Tatyana A; ABALAKINA, Tatyana V; SULEYMANOV, Ziya E; BANK, Sergey V; SOKOLNIKOVA, Olga B. 2021. "Customs and Logistics Activity in Geopolitical and Economic Changes: Problems, Strategies, and Risks" In: Frontier Information Technology and Systems Research in Cooperative Economics, Springer, Cham. Vol. 316, pp. 1105-1115. 
Mikhail B. Rumyantsev, Vladislav Yu. Turanin, Sergey Yu. Sumenkov, Marina G. Smirnova y Esita E. Ganaeva

614 The modern law-making process: structure and main problems

LEINO, Päivi; CURTIN, Deirdre. 2017. "In search of transparency for EU lawmaking: Trilogues on the cusp of dawn" In: Common market law review. Vol. 54, No. 6, pp. 1673-1712.

MAGRADZE, Tengiz. 2020. "Tax Administration In The Russian Federation: Current Problems And Development Prospects" In: Colloquium-journal. No. 5 (57).

MCNAMARA, Luke; QUILTER, Julia; HOGG, Russell; LOUGHNAN, Arlie; DOUGLAS, Heather; BROWN, David; FARMER, Lindsay. 2019. "Understanding processes of criminalisation: Insights from an Australian study of criminal law-making" In: Criminology \& Criminal Justice. Available online. In: http://dx.doi.org/10.1177/1748895819868519. Consultation date: $28 / 12 / 2020$.

NEMIROVA, Gulzida I; SAVELYEVA, Tatiana I. 2020. "Significance assessment of the risk management system to improve the quality of customs service provision" In: Economic Consultant. Vol. 3, pp. 42-52.

ROMANOVSKAYA, Elena V; ANDRYASHINA, Natalia S; KUZNETSOVA, Svetlana N; SMIRNOVA, Zhanna V; IVONINA, Oksana G. 2020. "Digital Technologies in Russia: Trends, Place and Role in Economy" In: Institute of Scientific Communications Conference. Vol. 155, No. 45, pp. 344-351.

UMEDOV, Kadriddin Minhodzhidinovich. 2021. "A concept of operational lawmaking technology” In: SHS Web of Conferences, EDP Sciences. Vol. 94, pp. 432-458.

WIDIATI, Ekawestri Prajwalita. 2018. "Efficient public participation in the local law-making process" In: Yuridika. Vol. 33, No. 3, pp. 389-401. 

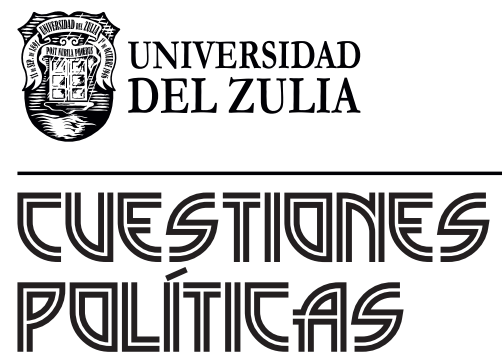

Vol.39 No 69

Esta revista fue editada en formato digital y publicada en julio de 2021, por el Fondo Editorial Serbiluz, Universidad del Zulia. Maracaibo-Venezuela 